\title{
DINAMIKA DUKUNGAN SUAMI PADA KECEMASAN IBU NIFAS DALAM RUMAH BULAT
}

\author{
Mernon Yerlinda Carlista Mage ${ }^{1}$, Susana Prapunoto, \& A. Ign. Kristijanto \\ Magister Sains Psikologi, Fakultas Psikologi, Universitas Kristen Satya Wacana Salatiga, Jalan Diponegoro $52-$ \\ 60, Salatiga, Indonesia \\ Korespondensi: \\ le-mail: mernonmage@gmail.com
}

\begin{abstract}
This study aims to explore the role of husbands' support in assisting their wives to overcome anxiety during puerperium. The study took place at Rumah Bulat (a traditional house especially designed for mothers in their puerperial period and their babies) in Putun Villange, Central Southern Timor, East Nusa Tenggara, Indonesia. A qualitative approach was employed, participated by two married couples who had undergone or were undergoing postpartum period in Rumah Bulat. Descriptive analysis using thematic coding procedure suggests four types of husband support to their wives during puerperal period: instrumental support, psychosocial support, emotional support, and spiritual support. Each support was conveyed by each participant in different forms and had an impact in reducing postpartum maternal anxiety. The study's result provides reference to the government and local communities regarding how to provide support for women in the puerperal period,

which is still understudied.
\end{abstract} Article history:

Received 18 May 2019

Received in revised form 28 August 2019

Accepted 13 February 2020

Available online 2 April 2020

\begin{abstract}
Abstrak - Penelitian ini bertujuan mendeskripsikan bentuk dan dinamika dukungan suami terhadap kecemasan istri pada masa nifas. Studi ini dilakukan di Rumah Bulat (sebuah rumah adat yang khusus dibangun untuk perawatan ibu dan bayi pada masa nifas) di Desa Putun, Kabupaten Timor Tengah Selatan, Nusa Tenggara Timur, Indonesia. Penelitian ini menggunakan metode kualitatif dengan dua pasangan suami-istri yang sudah atau sedang menjalani nifas dalam Rumah Bulat sebagai partisipan. Hasil analisis deskriptif menggunakan teknik analisis tematik menunjukkan bahwa terdapat empat bentuk dukungan suami yang diberikan selama ibu nifas berada dalam pengasingan, yaitu dukungan instrumental, dukungan psikososial, dukungan emosional, dan dukungan spiritual. Setiap dukungan disampaikan masing-masing partisipan dengan cara yang berbeda-beda dan berdampak dalam menurunkan kecemasan ibu nifas. Hasil penelitian ini dapat menjadi acuan, baik bagi pemerintah maupun komunitas setempat, mengenai bagaimana memberikan dukungan bagi ibu nifas yang masih belum banyak diteliti.
\end{abstract}

Kata Kunci: dukungan suami; ibu nifas; kecemasan; masa nifas; postpartum 


\section{PENDAHULUAN}

Budaya perawatan ibu pada masa nifas dengan cara pengasingan masih banyak dijumpai di berbagai komunitas di Indonesia, khususnya di wilayah Indonesia bagian Timur. Salah satu suku yang menjadikan tradisi pengasingan bagi ibu dan bayi pada masa nifas sebagai suatu kearifan lokal adalah suku Timor, di Kabupaten Timor Tengah Selatan (TTS), Provinsi Nusa Tenggara Timur (NTT).

Tradisi pengasingan di TTS mengharuskan ibu dan bayi berdiam dalam rumah adat Timor, yang disebut Rumah Bulat (bahasa asli Timor: ume kbubu) dengan kondisi rumah yang berbentuk bulat, beratap material alang-alang yang hampir menyentuh tanah, berdiamater 3-6 meter, pintu berbentuk setengah lonjong dengan ketinggian kurang dari 1 meter, berlantaikan tanah, tidak memiliki ventilasi, serta perapian yang harus terus menyala untuk menghangatkan kondisi ruangan (Karwur, Yamri, \& Kristiani, 2016). Selain itu, terdapat juga proses pengasapan (se'i) bagi ibu dan bayi dengan meletakkan arang panas di bawah kolong tempat tidur ibu dan bayi agar sang bayi menjadi lebih kuat dan luka-luka ibu pasca melahirkan lebih cepat pulih. Ibu juga menjalani tatobi, yaitu pengompresan air panas yang diyakini dapat mengeluarkan darah kotor yang masih tersisa di dalam tubuh. Selama menjalani masa nifas dalam Rumah Bulat, ibu hanya diperbolehkan mengonsumsi makanan berupa jagung bose (makanan khas suku Timor) yang berfungsi mencegah timbulnya luka-luka di dalam tubuh. Masyarakat Timor meyakini bahwa tradisi ini dapat bermanfaat untuk mempercepat pemulihan kesehatan ibu setelah melahirkan dan menjadikan sang bayi lebih kuat (Athena \& Rachmalina, 2014).

Selama menjalani masa nifas dalam Rumah Bulat, ibu dan bayi berpotensi mengalami berbagai gangguan fisik akibat pencemaran udara dari bahan bakar biomasa atau kayu bakar, seperti mengalami Infeksi Saluran Pernapasan bagian Atas (ISPA) (Christiani, Budiyono, \& Onny, 2018). Berdasarkan data Dinas Kesehatan Nusa Tenggara Timur (2014), ISPA merupakan penyumbang tertinggi angka kematian ibu dan bayi di Kabupaten TTS. Hal ini disebabkan oleh pencemaran udara dari bara api yang dihirup oleh ibu dan bayi selama berada dalam Rumah Bulat. Data Badan Pusat Statistik (2017) menunjukkan bahwa ISPA merupakan jenis penyakit dengan jumlah kunjungan terbanyak pada tahun 2016 di Puskesmas Kecamatan Nunkolo, yaitu sebanyak 1,222 kali, diikuti keluhan nyeri otot (427 kali) dan sakit kepala (391 kali). Studi Athena dan Rachmalina (2014) melaporkan bahwa proporsi gangguan kesehatan ibu maupun bayi yang melakukan $s e^{\prime} i$ dalam kurun waktu 1 tahun juga cukup tinggi, yaitu masing-masing sebesar 37.4\% dan 43.3\%. 
Ibu yang menjalani masa nifas dalam Rumah Bulat melaporkan bahwa perawatan pasca melahirkan di Rumah Bulat bukan hanya menyebabkan gangguan pernafasan, tetapi juga sakit dan nyeri pada pinggang, punggung, dan kepala (Dhanang, 2016). Ruang yang sempit, gelap, dan panas juga menyebabkan kesulitan bagi ibu untuk merawat diri dan bayinya. Menjalani tatobi dan se'i membuat tubuh ibu terasa panas dan melepuh. Ibu sering merasa cemas dengan kodisi bayinya yang terus menghirup asap, terekspos oleh udara panas, bahkan hingga batuk berulang kali, tetapi tidak diizinkan keluar dari Rumah Bulat. Ibu juga merasakan kecemasan dan ketakutan ketika harus berada sendirian bersama bayinya, sementara sang suami sedang bekerja dan tidak ada kerabat yang menemani. Kebingungan, kelelahan, kejenuhan, dan perasaan bersalah semakin membuat ibu merasa tidak tenang.

Pada umumnya, masa nifas adalah masa seorang ibu akan mengalami banyak perubahan, seperti perubahan peran, perubahan fisiologis, dan perubahan psikologis yang signifikan. Hal ini menimbulkan suatu kondisi krisis di mana ibu harus mampu beradaptasi dengan aktivitas terkait peran barunya dalam minggu-minggu atau bulan-bulan pertama setelah melahirkan. Sebagian ibu nifas menunjukkan kemampuan penyesuaian yang baik, tetapi tidak sedikit yang menunjukkan reaksi emosional negatif, gangguan psikologis, bahkan kecemasan akut yang berujung pada kematian (Herlina, Widyawati, \& Maryono, 2009). Kemampuan menyesuaikan diri dengan peran yang baru hanya ditemui pada ibu yang telah beberapa kali menjalani masa nifas dalam Rumah Bulat. Bagi ibu yang baru pertama kali menjalani masa ini (melahirkan anak pertama), berada di Rumah Bulat pasca melahirkan bersama bayi adalah sesuatu yang baru dan mengejutkan. Meskipun, ibu sendiri sudah sering melakukan aktivitas di dalam Rumah Bulat, seperti memasak, tetapi keberadaan bayi yang baru lahir menimbulkan kecemasan yang berbeda.

Kecemasan merupakan suatu keadaan emosional yang tidak menyenangkan dan ditandai dengan rasa takut, serta gejala fisik yang menegangkan atau tidak diinginkan (Nevid \& Rathus, 2005). Sekitar 10-20\% kondisi cemas terjadi pada ibu pasca melahirkan dan cenderung berlangsung hingga beberapa bulan bahkan bertahun-tahun setelahnya. Sindrom ini diawali dengan adanya gangguan masa kehamilan, stres psikososial, dan dukungan sosial yang tidak memadai (Dewi, 2018). Oleh karena itu, penting bagi anggota keluarga, khususnya suami dalam konteks kebudayaan ini, untuk memahami dengan baik bagaimana memberikan dukungan bagi istri selama menjalani masa nifas dalam Rumah Bulat. Adapun, kondisi dan kebutuhan perempuan nifas di Rumah Bulat jelas berbeda dengan perempuan yang mendapatkan pelayanan dengan fasilitas kesehatan memadai, tanpa ada keterikatan pada tradisi. Dengan memahami kecenderungan kecemasan yang dapat 
dialami istri dan kemampuan memberikan dukungan secara tepat, maka suami dapat sangat membantu istri melewati masa nifasnya dengan aman dan bayi dapat tetap berada dalam kondisi sehat.

\section{Tradisi Masa Nifas di Rumah Bulat bagi Masyarakat Timor Tengah Selatan}

Tradisi masa nifas dalam Rumah Bulat bagi para ibu di Desa Putun, Kecamatan Nunkolo, Kabupaten Timor Tengah Selatan telah mengalami perubahan sosial, sehingga ibu tidak lagi dituntut untuk menjalani masa nifasnya sendirian tanpa ditemani oleh keluarga. Sekalipun proses persalinan harus dilakukan di puskesmas, tetapi masa nifas bagi ibu di Desa Putun wajib dijalani di Rumah Bulat. Selama masa nifas, ibu diizinkan keluar masuk Rumah Bulat kapan saja layaknya beraktivitas seperti biasa, sedangkan bayi harus terus berada dalam Rumah Bulat selama 4 minggu. Kondisi ini menuntut ibu untuk lebih banyak menghabiskan waktu bersama bayi dalam Rumah Bulat tersebut. Setelah 4 minggu, barulah bayi dapat dibawa keluar untuk didoakan di gereja. Ritual tatobi (pengompresan) dan sei (pengasapan) wajib dilakukan oleh ibu sebanyak dua kali sehari, yaitu pagi dan sore. Selain itu, ibu hanya boleh mengonsumsi jagung bose tanpa dicampur dengan jenis makanan lainnya selama menjalani masa nifas dalam Rumah Bulat (Prapunoto, Mage, \& Wattimury, 2019). Kondisi-kondisi tersebut menimbulkan kecemasan dan kegelisahan sang ibu, terutama pada kondisi bayi.

Seorang ibu yang telah menjalani masa nifas kedua kali di Rumah Bulat, dalam wawancara bersama peneliti, menceritakan pengalaman pertama yang membuatnya memutuskan untuk tidak menjalani tradisi tersebut. Hal ini disebabkan karena kekhawatirannya pada kondisi sang bayi yang terlihat pucat dan timbul bintik-bintik merah pada wajah yang disebabkan oleh hawa panas. Selain itu, pada masa nifasnya yang pertama, ibu tidak diizinkan untuk ditemani oleh siapa pun, kecuali oleh suaminya sendiri. Tidak boleh ada kerabat yang berkunjung karena pada saat itu tradisi tersebut masih sangat primitif dan belum ada kebijakan dari pemerintah. Oleh karena kecemasan, ketakutan, dan keterbatasan dirinya, ibu perlu berusaha lebih keras untuk melewati masa-masa sulit tersebut. Meskipun ibu memutuskan untuk tidak lagi menjalani tradisi, tetapi adat tetap wajib dijalankan. Pada masa nifasnya yang kedua, ibu merasa telah mendapatkan banyak kemudahan karena kebijakan pemerintah daerah yang mengizinkan ibu untuk dikunjungi dan ditemani oleh orang-orang terdekat, bahkan suami wajib mengupayakan agar istrinya tidak sendirian bersama bayi di dalam Rumah Bulat tersebut. Dalam keadaan tersebut, kehadiran suami sangat dibutuhkan untuk meringankan dan mengurangi kecemasan yang dialami oleh ibu. 


\section{Dukungan Suami pada Ibu Nifas}

Dukungan sosial merupakan bantuan yang diterima dan dirasakan seseorang pada situasi tertentu oleh orang-orang tertentu (Kef, 2002). Werdayanti (2013) menyatakan bahwa dukungan sosial adalah kebutuhan manusiawi yang sangat berpengaruh untuk mengurangi dan mengatasi gangguan psikologis yang dialami seseorang dalam kondisi tertentu. Dukungan sosial bagi ibu pasca melahirkan dapat berasal dari keluarga, yaitu suami, orang tua, kerabat, maupun pihak medis yang membantu proses persalinan. Pada ibu yang menjalani masa nifas dalam Rumah Bulat, dukungan sosial paling banyak didapat melalui kehadiran suami.

Dalam studi ini, diasumsikan ibu dalam Rumah Bulat akan membutuhkan dukungan suami karena ibu dan bayi berada dalam kondisi lingkungan yang rentan mengalami gangguan fisiologis dan psikologis. Kondisi tersebut tergambar melalui keberadaan ibu dan bayi dalam ruangan yang penuh asap, kondisi ruangan tidak bersih, menjalani ritual tatobi dan se'i, serta ibu dan bayi dilarang keluar selama beberapa waktu. Suami adalah sosok yang diharapkan bertanggung jawab terhadap istri. Meskipun, dalam perspektif tradisi pengasingan ini dukungan dapat saja berasal dari keluarga, tetapi keberadaan suami adalah yang paling mendapatkan izin secara adat untuk terus menemani istri selama berada di Rumah Bulat. Artinya, suami diharapkan untuk selalu siap sedia selama masa tradisi tersebut.

Goldberger dan Breznitz (1982) menegaskan bahwa dukungan suami merupakan hubungan yang bersifat menolong dan mempunyai nilai khusus bagi istri sebagai adanya ikatan paling positif. Selain itu, Cohen dan Syme (1985) berpendapat bahwa kedekatan hubungan, sumber utama penyedia dukungan, dan kualitas pertemuan merupakan hal-hal penting yang membuat dukungan sosial pasangan (suami-istri) lebih bermakna daripada bentuk relasi lain. Periode nifas tentu menimbulkan banyak kecemasan yang memicu ibu memberikan respons negatif dalam merawat bayinya dan hal ini berdampak pada kualitas hidup ibu itu sendiri. Webster, Nicholas, Velacott, Cridland, dan Fawcett (2011) menyatakan bahwa dukungan sosial dari suami menentukan kualitas dan kebahagiaan hidup ibu, khususnya pada masa nifas. Kitzinger (1988) juga menyatakan bahwa kehadiran dan peran suami dalam memenuhi berbagai kebutuhan ibu pasca melahirkan sangat berpengaruh pada kondisi kesehatan ibu secara psikologis.

Oktaputrining, Susandi, dan Suroso (2017) menyatakan bahwa dukungan suami dapat mengurangi kecemasan dan ketakutan ibu pasca melahirkan. Dukungan fisik dan psikologis yang diberikan oleh suami terhadap ibu yang baru melahirkan akan memampukan ibu beradaptasi dengan fase-fase perubahan peran yang dialami. Hasil penelitian Anisa dan Nurfitria (2015) juga 
menunjukkan bahwa pemberian dukungan sosial oleh suami berdampak positif pada ibu di masa nifas. Dampak positif yang dirasakan oleh ibu tersebut adalah produksi air susu ibu (ASI) yang semakin lancar, memelihara semangat dalam memberikan ASI kepada anaknya, merasakan kenyamanan, dan berkurangnya beban yang dihadapi.

\section{Konseptualisasi Masalah}

Berkaitan dengan ketentuan tradisi budaya, khususnya tradisi pengasingan ibu dan bayi dalam Rumah Bulat, bentuk dukungan suami secara tradisional belum banyak diidentifikasi. Kondisi keterasingan tentu menuntut dukungan suami yang jauh lebih besar dibandingkan dengan kondisi persalinan dan masa nifas pada umumnya. Apabila masa nifas dijalani dalam lingkungan rumah inti yang bersih dan disertai fasilitas yang aman dan nyaman, maka tidak terlalu menimbulkan kecemasan pada ibu. Selain itu, suami juga dapat lebih percaya akan kesehatan istri dan bayinya bila keduanya berada dalam kondisi lingkungan nifas yang layak dan terjamin. Namun, berada dalam Rumah Bulat dengan berbagai keterbatasan ketika ibu masih dalam kondisi lemah pasca melahirkan dan bayi baru lahir yang harus terpapar asap api selama kurang lebih 1 bulan membuat suami perlu bekerja lebih keras untuk mengantisipasi konsekuensi terburuknya. Oleh karena itu, penelitian ini bertujuan untuk mengidentifikasi dan mendeskripsikan bentuk-bentuk dukungan suami terhadap istri selama masa nifas di Rumah Bulat melalui pendekatan kualitatif.

\section{METODE}

\section{Partisipan}

Partisipan primer dalam penelitian ini adalah ibu yang sedang berada dalam Rumah Bulat dan ibu yang pernah menjalani masa nifas dalam Rumah Bulat. Sementara itu, partisipan sekunder dalam penelitian ini adalah suami dari kedua partisipan primer. Partisipasi dari pasangan yang sudah pernah dan baru pertama kali menjalani masa nifas di Rumah Bulat memungkinkan untuk dilakukan observasi tentang perbedaan dinamika dukungan suami terhadap kecemasan ibu yang baru pertama kali menjalani masa nifas dalam Rumah Bulat dan yang sudah lebih dari satu kali.

Peneliti menggunakan teknik purposive sampling dalam menentukan kriteria partisipan. Partisipan yang dipilih adalah partisipan dengan ciri-ciri sebagai berikut: 1). Pasangan menikah, dengan kategori istri yang baru pertama dan yang sudah dua kali atau lebih menjalani tradisi nifas dalam Rumah Bulat; 2). Partisipan merupakan suku asli Timor dan warga asli desa Putun; serta 
3). Usia pasangan pasangan di antara 25-35 tahun. Akses pada partisipan penelitian dimulai dengan pendekatan pada Kepala Desa Putun yang banyak memberikan informasi terkait tradisi, kemudian mengantarkan peneliti pada subjek penelitian yang dibutuhkan.

Data dari dua pasangan yang berpartisipasi dalam studi ini ditampilkan dalam Tabel 1 sebagai berikut.

Tabel 1.

Data Partisipan Penelitian

\begin{tabular}{lcccc}
\hline \multirow{2}{*}{ Data/Identitas } & \multicolumn{2}{c}{ Partisipan A } & \multicolumn{2}{c}{ Partisipan B } \\
\cline { 2 - 5 } & \multicolumn{2}{c}{ Suami } & Istri & \multicolumn{2}{c}{ Suami } & Istri \\
\hline Usia & 31 tahun & 29 tahun & 35 tahun & 30 tahun \\
Pendidikan Terakhir & SMP & SD & SMP & SMP \\
Pekerjaan & \multicolumn{2}{c}{ Petani } & \multicolumn{2}{c}{ Petani } \\
Agama & \multicolumn{2}{c}{ Kristen } & \multicolumn{2}{c}{ Kristen } \\
Asal & \multicolumn{2}{c}{ Desa Putun } & Desa Putun \\
Jumlah anak & \multicolumn{2}{c}{ 1 orang } & 2 orang \\
Usia anak sekarang & \multicolumn{2}{c}{ tahun } & 5 tahun 1 minggu \\
\hline
\end{tabular}

\section{Desain}

Penelitian ini menggunakan desain penelitian kualitatif deskriptif. Dukungan sosial suami ditelusuri berdasarkan pendekatan psikologi indigenous, yakni kajian perilaku seseorang maupun sekelompok orang berdasarkan konsep budaya yang dianut oleh kelompok tersebut.

\section{Prosedur}

Pengumpulan data yang digunakan mencakup teknik wawancara mendalam dan observasi partisipatif. Wawancara menggunakan pedoman semi terstruktur yang dibantu oleh penerjemah lapangan mengingat partisipan tidak mahir dalam berbahasa Indonesia. Observasi partisipatif dilakukan dengan kondisi peneliti berada bersama partisipan dan bayi dalam Rumah Bulat, di mana peneliti mengamati ekspresi, respons, dan perilaku partisipan selama penelitian berlangsung.

Wawancara kepada partisipan dilakukan sebanyak tiga kali dengan durasi setiap wawancara adalah sekitar 1-2 jam. Pertanyaan awal berkaitan dengan identitas partisipan, ketentuan-ketentuan terkait tradisi nifas di Rumah Bulat, pengalaman-pengalaman psikologis dalam Rumah Bulat, masalah-masalah yang dihadapi, dukungan-dukungan yang diberikan suami, serta pertanyaan lebih dalam mengenai dampak dukungan yang diberikan suami dalam mengurangi dan mengatasi kecemasan ibu dalam pengasingan. Percakapan direkam menggunakan aplikasi rekaman audio pada 
telepon genggam. Teknik observasi dilakukan dengan mengamati dan mencatat setiap aktivitas nonverbal selama peneliti berinteraksi dengan partisipan.

\section{Teknik Analisis}

Data wawancara yang terkumpul diolah menggunakan langkah-langkah kualitatif menurut Sugiyono (2011), yaitu: 1). Transkrip, artinya data yang dikumpulkan dalam rekaman, kemudian didengarkan kembali untuk dituliskan dalam bentuk verbatim secara utuh setiap kata-katanya; 2). Reduksi, artinya data yang terkumpul direduksi menjadi data yang sesuai dengan tujuan penelitian; 3). Pengolahan tunggal, artinya data dirangkum berdasarkan ide-ide utama dan tema masingmasing; serta 4). Pengkodean, artinya setelah data disusun dengan benar, data dikodekan menggunakan angka pada bagian-bagian yang dianggap telah memenuhi kategori atau aspek penelitian.

Kredibilitas data diuji menggunakan teknik triangulasi, yaitu teknik pengujian validitas data yang menggunakan sesuatu yang lain di luar data yang dikumpulkan sebelumnya. Penelitian ini menggunakan triangulasi sumber, di mana data yang terkumpul diperiksa silang dengan data yang diperoleh dari sumber data sekunder. Dalam penelitian ini, sumber data sekunder meliputi hasil wawancara dengan kepala desa, saudara partisipan, dan beberapa kerabat yang sering datang mengunjungi partisipan selama masa nifas dalam Rumah Bulat.

Penelitian dilakukan di Desa Putun, Kecamatan Nunkolo, Kabupaten Timor Tengah Selatan, Provinsi Nusa Tenggara Timur sebagai salah satu desa yang masih menjalankan tradisi masa nifas bagi ibu dan bayi di dalam rumah bulat.

\section{ANALISIS DAN HASIL}

\section{Ketentuan Tradisi Nifas Dalam Rumah Bulat}

Menurut hasil wawancara dengan Kepala Desa Putun, istilah pengasingan yang ditandai dengan larangan kunjungan atau tidak boleh ada yang menemani ibu dan bayi selama 30 hari dalam Rumah Bulat saat ini tidak lagi diterapkan di Desa Putun. Hal ini disebabkan adanya peraturan yang dikeluarkan oleh Pemerintah Kabupaten Timor Tengah Selatan terkait pelayanan kesehatan ibu dan bayi baru lahir yang harus dilaksanakan di puskesmas, rumah sakit, atau tenaga bidan. Namun, beberapa masyarakat Desa Putun bersikeras mempertahankan tradisi, sehingga masa nifas ibu dan bayi tetap harus dijalankan di Rumah Bulat setelah proses persalinan di puskesmas. 
Sejak hari pertama ibu dan bayi berada dalam Rumah Bulat, ibu dapat dikunjungi oleh siapapun, tetapi tidak boleh ditemani menginap selain oleh suami atau keluarga dekat. Bayi baru boleh dibawa keluar setelah 3 minggu untuk dibawa ke gereja. Tradisi tatobi (pengompresan) menggunakan air panas diterapkan kepada ibu sebanyak dua kali sehari, yaitu pada pagi dan sore. Tatobi dapat dilakukan oleh ibu sendiri, suami, atau keluarga dekat yang ada pada saat itu. Proses tatobi wajib dilakukan secara rutin oleh ibu dengan benar-benar menekan bagian tubuh tertentu agar darah kotor dalam tubuh dapat keluar dan tidak menyebabkan penyakit nantinya. Selama berada dalam Rumah Bulat, ibu hanya diperbolehkan mengonsumsi jagung bose. Suasana dalam Rumah Bulat harus tetap hangat, yakni dengan adanya tungku perapian di dalam rumah dan arang panas tepat di kolong tempat tidur ibu dan bayi.

\section{Pengalaman Psikologis dan Masalah di Rumah Bulat}

Kedua partisipan, dalam hal ini istri yang menjalani masa nifas menyampaikan pengalaman yang kurang lebih sama, khususnya pada pengalaman pertama. Pengalaman pertama selalu dipenuhi dengan kecemasan berlebih pada kondisi bayi. Bayi yang berada dalam ruangan gelap, tertutup, sempit, dan dipenuhi asap jelas rentan mengalami gangguan pernapasan.

Selama ini, yang berat masalahya itu waktu pertama kali melahirkan. Badan terlalu lemah untuk jaga ini anak. Butuh waktu lama dan setengah mati, tambah ini anak menangis sepanjang hari sepanjang malam, tambah setengah mati saya waktu itu. Dia juga batuk, kami cuma bisa kasikurang asap atau kasmati api, tapi tetap saja takut, saya setengah mati.

Kecemasan tersebut membuat partisipan merasa tidak tenang dan lebih sensitif dalam merespons keadaan. Selain itu, partisipan mudah panik dan ingin segera mendapat pertolongan, khususnya pada saat gejala buruk muncul pada bayinya. Partisipan sering menangis dan menunjukkan perasaan tidak berdaya, serta ingin segera keluar dari Rumah Bulat tersebut. Partisipan B justru memutuskan untuk tidak lagi bersedia menjalani tradisi tersebut pada masa nifasnya yang berikut.

Berdasarkan pengamatan, peneliti juga mendapati respons partisipan B (istri) yang beberapa kali tidak banyak berbicara dengan suaminya (memilih diam) saat emosinya sedang tidak stabil. Hal ini membuat suami partisipan berusaha lebih keras untuk memberikan dukungan. 


\section{Dukungan Suami}

Dukungan suami pada partisipan selalu dimulai dengan menyediakan segala kebutuhan istri mulai dari masa kehamilan, persalinan, hingga masa nifas. Suami menyiapkan kebutuhan dasar, seperti bahan makanan (beras, jagung bose), air, kayu bakar, perlengkapan bayi, dan lain sebagainya. Suami selalu membantu meringankan pekerjaan istri, seperti memasak, mencuci, membeli bahan makanan, dan mengolah ladang. Dukungan ini dapat diklasifikasikan sebagai dukungan instrumental. Suami juga selalu memastikan agar istrinya memiliki waktu lebih banyak untuk merawat bayi dan tidak mengerjakan pekerjaan lainnya. Dalam upaya ini, suami partisipan melibatkan bantuan dari orang-orang terdekat, sehingga merefleksikan bentuk dukungan psikososial. Selain itu, bila kondisi dalam Rumah Bulat yang penuh asap memperparah kondisi istri dan bayi, maka akan dilakukan pengurangan arang dan pengecilan api agar hawa panas dapat berkurang. Suami selalu berusaha agar istri dan bayinya tidak sendirian dalam Rumah Bulat. Hal ini ditandai dengan usaha suami partisipan A meminta tetangga atau orang-orang sekitar untuk menemani istrinya.

Kalo saya harus ke kebun karna memang musim kita tanam, tapi pas ibu deng mea ada di rumah, na saya selalu minta nyadu di samping ko datang jaga mereka dua. Temani mereka sampe sore saya pulang. kalo tidak na minta sodara dong yang pi kebun, supaya saya yang temani mereka di rumah. Karna ini kita pung anak pertama, dia juga baru pertama, jadi masih sulit sekali sendiri.

Proses tatobi dan se'i juga dibantu oleh suami. Selain itu, suami juga banyak meminta saran dari kepala desa atau bidan desa untuk mendapatkan informasi yang dapat membantunya merawat istri dan bayinya.

Kadang kalo pas ketemu bapa desa di kebun, ato pas pi rumah itu saya ju tanyatanya bagemana supaya ini ibu deng mea tidak sakit kena asap. Mama pendeta juga datang doa kasi kami, kadang ibu bidan pas ke puskesmas juga saya jemput datang ke rumah ko cek ini anak deng dia pung mama.

Mengenai dukungan emosional, partisipan (istri) mengaku bahwa suaminya menjadi lebih sabar dan begitu memahami kondisinya. Tanpa banyak berbicara, suami dengan segera berusaha menenangkan bayi, banyak mendengar keluh kesah istri, dan memberikan waktu istri beristirahat di rumah inti sementara suami menemani bayi di Rumah Bulat. 
Kalo saya su rasa terlalu sakit, kepala juga pusing, tambah ini anak menangis, pokonya su cape itu saya kadang cepat marah. Buat apa-apa marah, kadang diam. Na itu, dia pung bapa ini banyak kasi tenang, suruh saya pi tidur di dalam, atau dia juga dengar saja, tidak balas saya omong, dia masak, dia doa kasi kita, dia jaga ini anak, jadi saya juga rasa lebih baik begitu.

Dukungan yang diberikan suami kepada partisipan lebih daripada sekadar memberikan perhatian melalui keberadaannya secara fisik yang dekat dengan partisipan, tetapi juga melalui berbagai tindakan nyata. Tindakan-tindakan tersebut dapat berasal dari dirinya secara langsung maupun melalui pertolongan orang lain. Hal ini nyata dalam pengamatan peneliti bahwa selalu ada kerabat, bahkan istri kepala desa atau pendeta yang datang dan mendoakan kedua partispan agar keluarga partisipan selalu dikuatkan dan hal ini secara tidak langsung juga menunjukkan bentuk dukungan spiritual.

Kedua partisipan (istri) memaknai dukungan sebagai motivasi atau pendorong untuk tetap bertahan. Seperti halnya partisipan B yang akhirnya memutuskan untuk tetap menjalani masa nifas kedua kalinya dalam Rumah Bulat karena partisipan meyakini bahwa keberadaan suaminya akan sangat membantu. Hal yang sama juga dikemukakan partisipan A. Menurutnya, meskipun, pada masa-masa awal berada bersama bayi dalam Rumah Bulat terasa begitu tertekan, tetapi dukungan suami yang diberikan sesuai kebutuhannya semakin mampu mengurangi kecemasan yang dialami.

\section{DISKUSI}

Hasil penelitian menunjukkan adanya empat dukungan suami, yaitu dukungan instrumental, dukungan psikososial, dukungan emosional, dan dukungan spiritual.

Dukungan suami berupa ketersediaan sumber daya, barang, jasa, keuangan, dan waktu yang disediakan merupakan dukungan yang paling banyak diutarakan oleh kedua partisipan. Terdapat beberapa kesamaan dan perbedaan dari tindakan-tindakan praktis yang diberikan suami kepada istrinya masing-masing. Tindakan-tindakan tersebut tidak hanya untuk memenuhi kebutuhan dasar saja, tetapi juga untuk mencegah dan memulihkan kondisi fisik ibu dan bayi secara lebih baik. Taylor, Letitia, dan David (2009) mengidentifikasi bentuk dukungan berupa upaya menyediakan barang dan memberikan jasa sebagai bentuk dukungan instrumental. Cremonese dkk. (2017) menyatakan bahwa dukungan instrumental merupakan salah satu bentuk dukungan yang hasilnya dapat dilihat dan dirasakan secara nyata. Artinya, dukungan instrumental dapat membawa perubahan pada kondisi psikologis dan emosional partisipan. Negron, Martin, Almog, Balbierz, dan 
Howell (2013) menyatakan bahwa dukungan instrumental memainkan peranan penting dalam pemenuhan kebutuhan dasar ibu pada masa postpartum, serta mampu memulihkan kondisi fisik dan emosional sang ibu. Dampak yang dirasakan pada diri partisipan karena dukungan fisik yang diberikan suami bersifat positif, yaitu perasaan dikasihi, terlindungi, dan diperhatikan yang dapat mengurangi kecemasan ibu. Selain itu, perasaan khawatir juga semakin berkurang karena kesiapsiagaan suami.

Dukungan lain yang juga teridentifikasi dalam penelitian ini adalah kebutuhan akan kehadiran suami untuk menemani istri selama berada di Rumah Bulat. Dalam pengamatan peneliti, khususnya pada partisipan B selama berada dalam Rumah Bulat, kondisi sebaliknya justru terjadi. Dibandingkan pasrtisipan A, yang mana suami meminta keluarga atau kerabat untuk menemani istri dan anaknya dalam Rumah Bulat saat dirinya berada di ladang, suami partisipan B lebih memilih meminta kerabat atau tetangga yang membantu mengurusi ladangnya, sehingga dapat sepenuhnya bersama istri dan anaknya di dalam Rumah Bulat. Ketika istri mengalami sakit, suami bersedia menjaga bayi dalam Rumah Bulat, sehingga istri dapat beristirahat lebih banyak dan merasa lebih nyaman di dalam rumah inti. Selain itu, suami partisipan juga banyak menolong dan merawat kondisi istri dan bayi sesuai dengan yang disampaikan oleh bidan desa, kepala desa, dan pendeta yang ditemui maupun yang datang berkunjung. Hal ini sangat berdampak positif bagi kondisi partisipan selama menjalani masa nifas.

Bentuk-bentuk dukungan sebagaimana disampaikan di atas diidentifikasi sebagai dukungan psikososial. Dukungan psikososial yang dimaksud mengacu pada dukungan-dukungan yang diberikan suami untuk mengurangi berbagai gejala depresi atau gangguan psikologis dengan cara suami melibatkan pihak lain. Berdasarkan dukungan psikososial yang diterima, kedua partisipan mampu mengatasi kecemasan dan ketakutan yang dialami. Perasaan aman dan nyaman mulai muncul, serta tidak lagi merasa kesepian karena kebutuhan sosial terpenuhi melalui dukungan suami. Dennis dan Hodnett (2007) menyatakan bahwa dukungan psikososial yang diberikan oleh orang sekitar efektif untuk mengurangi gejala depresi ibu pada masa nifas. Tindakan ini merupakan bentuk kesadaran suami akan kebutuhan sosial partisipan. Hal penting yang menjadi perhatian dalam memberikan dukungan adalah bahwa partisipan membutuhkan orang lain untuk mengatasi berbagai persoalan psikologis yang dapat memberikan dampak positif bagi kedua partisipan.

Dukungan lainnya yang teridentifikasi ialah dukungan emosional. Hal ini tercermin melalui pernyataan partisipan A yang menyatakan bahwa dalam kondisi ketika dirinya merasakan sakit dan khawatir dengan kondisi bayi, maka partisipan cenderung melampiaskan amarah dan 
kegelisahannya kepada suami. Dalam hal ini, suami partisipan menunjukkan sikap lebih banyak mengalah dan banyak mendengarkan keluh-kesah istri daripada merespons dengan cara negatif, khususnya pada masa-masa kehamilan dan pasca melahirkan. Di samping itu, partisipan juga melihat bahwa suami menunjukkan sikap lebih sabar dalam menghadapi emosinya yang terus berubah, serta selalu memberikan waktu dan tenaga untuk menjadi suami siaga. Partisipan B menyampaikan bahwa dukungan emosional yang diberikan oleh suami adalah bentuk-bentuk yang lebih sederhana, seperti menunjukkan kasih sayang dengan memeluk istri, serta menggendong dan bermain dengan bayi sebelum berangkat ke ladang. Sang suami juga memberikan perhatian pada seluruh kebutuhan istri dan bayinya, terlebih kebutuhan secara emosional dengan mendengarkan keluh-kesah, merespons dengan jawaban-jawaban ramah dan menguatkan, serta membantu meredakan tangisan bayi.

Dukungan emosional berdampak sangat penting karena diberikan oleh suami partisipan. Dukungan ini dapat menunjukkan perasaan cinta, kepedulian, empati, dan simpati dari suami yang menimbulkan kepercayaan, kenyamanan, dan rasa aman bagi istri. Hal ini selaras dengan penelitian oleh Haga dkk. (2012) bahwa dukungan emosional dari orang-orang terdekat dapat membuat individu merasa berarti dan dikasihi, serta merasa aman dalam situasi-situasi stres yang dirasakan. Dampak yang dirasakan kedua partisipan berdasarkan dukungan emosional yang diberikan suami masing-masing adalah timbulnya niat dalam hati untuk turut bekerja keras, merasa semakin mencintai dan dicintai suami, tidak pernah merasa kekurangan, semakin mampu menemukan makna hidup, membangkitkan kesadaran akan tanggung jawab sebagai istri sekaligus ibu, dan lebih mampu mengontrol emosi negatif.

Terdapat pula dukungan lain yang diberikan suami kepada istrinya, yaitu dukungan dalam hal keyakinan dan spiritualitas. Partisipan A menyatakan bahwa setiap malam selama masa nifas, partisipan selalu memohon perlindungan, kekuatan, dan kesehatan dari Yang Maha Kuasa melalui doa yang dipimpin oleh suami. Perkataan doa yang diucapkan suami selalu memberikan penguatan bagi istri. Partisipan B menyampaikan bentuk dukungan suami yang sedikit berbeda. Suami partisipan B selalu menyediakan waktu untuk meminta kehadiran kepala desa atau pendeta maupun majelis gereja untuk datang berkunjung dan mendoakan keluarganya. Hal ini memberikan kekuatan lebih kepada istri, sehingga dapat semakin dekat pada Tuhan dan terus berpengharapan.

Dukungan spiritual sangat erat kaitannya dengan interaksi sistem sosial-budaya masyarakat Desa Putun. Setelah ibu dan bayi keluar dari Rumah Bulat, bayi harus dibawa ke gereja untuk didoakan, kemudian diperkenalkan kepada seluruh masyarakat melalui acara syukuran. Dukungan 
ini berdampak pada iman dan pengharapan yang terus bertumbuh. Kedua partisipan merasakan kesejahteraan dalam hati, serta mampu selalu bersyukur atas perlindungan Yang Maha Kuasa. Dukungan spiritual juga turut menunjukkan suatu kesatuan batin, yaitu suami mampu merasakan apa yang dirasakan oleh istri. Tindakan suami yang ditunjukkan melalui kesetiaan mendengarkan, membantu dalam pengambilan keputusan, memenuhi berbagai kebutuhan, bahkan mendoakan merupakan suatu bentuk pengajaran agar ibu nifas dapat belajar berbuat hal yang sama, serta untuk menjaga kondisi istri tetap sehat dan bebas dari gejala depresi. Penelitian oleh Zittel-Palamara, Cercone, dan Rockmaker (2009) melaporkan hampir 66\% ibu menemukan kekuatan melalui keyakinan agama. Salah satu kategori dukungan spiritual yang diungkapkan oleh Zittel dkk. adalah dukungan doa yang diberikan orang-orang sekitar. Kebutuhan berbasis spiritual disarankan untuk selalu disediakan bagi ibu pada masa nifas, baik oleh keluarga, tokoh agama, maupun masyarakat.

Semua dukungan sosial yang diberikan oleh suami sebagaimana telah dianalisis, selaras dengan penelitian Fairus dan Widiyanti (2014) bahwa dukungan psikologis dari suami membuat isteri melewati masa nifas dengan rasa bahagia dan sejahtera.

Semua jenis dukungan yang diupayakan oleh suami kedua partisipan sangat dipengaruhi oleh faktor sosial-budaya. Berbeda dengan dukungan suami pada umumnya, konteks tradisi pengasingan ini melibatkan kondisi bangunan fisik yang sangat tidak layak, keterbatasan fasilitas dan tenaga kesehatan, serta peraturan adat yang mempersempit jangkauan memperoleh dukungan. Selain berupaya memaksimalkan kebutuhan yang ada, pasangan partisipan juga meyakini bahwa tradisi tersebut merupakan cara terbaik bagi masyarakat untuk mempercepat pemulihan ibu, menjadikan bayi lebih kuat, serta membuat istri memaknai sendiri peran dirinya sebagai ibu.

Dalam hal pemaknaan inilah, tradisi nifas dalam Rumah Bulat semakin memperteguh makna filosofi Rumah Bulat itu sendiri, yaitu sebagai “ibu”. Bagi masyarakat suku Timor, Rumah Bulat merupakan simbol "perempuan" Timor yang rendah hati, lemah lembut, dan tangguh dalam menghadapi kerasnya hidup (Lake, 2014). Segala aktivitas yang berhubungan dengan kehidupan harus dimulai dari dalam Rumah Bulat. Oleh karena itu, suatu peristiwa kelahiran sebagai peristiwa dimulainya kehidupan seseorang juga harus dilakukan di dalam Rumah Bulat. Masyarakat percaya bahwa setiap ritual yang dijalankan oleh ibu dan bayi dalam Rumah Bulat memiliki nilai-nilai kehidupan yang harus dipertahankan. Tradisi ini memperlihatkan perjuangan seorang ibu dan suami melalui ketabahan, ketahanan, ketangguhan, rela berkorban, dan tidak putus asa. Kehadiran suami dengan berbagai dukungan dalam keterasingan ibu dan bayi semakin memperteguh nilai-nilai dalam tradisi tersebut. Secara spesifik, tradisi ini merupakan bentuk implementasi keyakinan masyarakat 
bahwa segala perawatan yang diterima ibu dan bayi selama masa nifas di dalam Rumah Bulat mampu menjadikan keduanya lebih sehat, khususnya bayi dapat bertumbuh menjadi anak yang tangguh melawan kerasnya alam.

Meskipun demikian, pada dasarnya tradisi ini menempatkan setiap keluarga dalam keadaan dilema untuk memilih melakukan tradisi dengan risiko terburuk adalah kematian ibu dan bayi akibat ISPA ataupun infeksi fisik lainnya karena kondisi rumah yang tidak higienis atau justru menolak dan dianggap mengabaikan peraturan yang telah diwariskan turun-temurun. Dalam rangkaian masalah yang ada, pada akhirnya partisipan tetap harus menjalankan tradisi dengan konsekuensi harus berupaya lebih keras agar keduanya dapat selamat melewati masa nifas dalam rumah bulat tersebut.

Studi ini menyatakan bahwa ibu yang menjalani tradisi nifas pertama kali menunjukkan gejala kecemasan yang jauh lebih tinggi dibandingkan ibu yang telah berpengalaman pada tradisi nifas dalam Rumah Bulat. Hal ini berdampak pada kebutuhan akan kehadiran dan dukungan suami yang lebih tinggi. Berbeda dengan ibu yang telah memiliki pengalaman nifas dalam Rumah Bulat sebelumnya, pengalaman serupa di masa lalu mampu memberikan pengetahuan dan kemampuan untuk mengatasi kecemasan yang timbul akibat tradisi tersebut.

Keterbatasan dalam penelitian ini adalah jumlah partisipan yang hanya sebanyak dua pasangan suami-istri saja. Salah satu partisipan dengan pengalaman nifasnya sudah berselang 4 tahun hanya mengandalkan memori dalam menyampaikan pengalamannya, sehingga memungkinkan adanya distorsi memori terhadap pengalaman tertentu. Ada juga kemungkinan bias akibat social desirability (keinginan sosial) karena istri tidak ingin kelemahan suami diketahui atau karena suami ingin terlihat baik.

\section{SIMPULAN DAN SARAN}

\section{Simpulan}

Berdasarkan hasil penelitian, ditemukan empat jenis dukungan suami bagi kecemasan ibu selama masa nifas di dalam Rumah Bulat, yaitu dukungan instrumental, emosional, psikososial, dan spiritual. Secara utuh, semua dukungan yang diberikan suami dalam penelitian ini memberikan dampak yang positif bagi istri dalam mengatasi kecemasannya selama pengasingan di Rumah Bulat. Selain itu, dukungan suami juga memperteguh nilai filosofi Rumah Bulat sebagai rumah ibu yang menghadirkan ketabahan, ketahanan, ketangguhan, rela berkorban, dan tidak putus asa. 


\section{Saran Teoretis}

Penelitian selanjutnya diharapkan dapat mempertimbangkan faktor pendidikan, baik formal maupun informal, serta faktor religiusitas masyarakat adat maupun aspek kearifan lokal lainnya dalam kaitannya dengan budaya pengasingan ibu pada masa nifas. Hasil penelitian ini dapat menjadi rujukan dalam merancang dan mengimplementasikan model psikologis berbasis kerarifan lokal untuk mengatasi kecemasan ibu dalam pengasingan.

\section{Saran Praktis}

Hasil penelitian ini dapat menjadi pedoman dasar bagi para pemegang kebijakan, khususnya pemerintah daerah dan petugas kesehatan desa untuk mensosialisasikan pentingnya dukungan sosial, khususnya dari suami bagi ibu nifas selama berada di dalam Rumah Bulat. Hasil penelitian ini juga diharapkan dapat memberikan referensi yang bermanfaat dalam mengantisipasi dampak negatif dari tradisi nifas di Rumah Bulat terhadap kesehatan ibu dan bayi, sehingga dapat diformulasikan strategi yang tetap mengakomodasi tradisi budaya tanpa menempatkan kesehatan dan keselamatan ibu dan bayi sebagai risikonya.

\section{UCAPAN TERIMA KASIH}

Ucapan terima kasih diberikan kepada seluruh partisipan di Desa Putun, Kecamatan Nunkolo yang telah terlibat dalam penelitian. Ucapan terima kasih juga diberikan kepada Dinas Penanaman Modal dan Pelayanan Terpadu Satu Pintu (DPMPTSP), Dinas Kesatuan Bangsa dan Politik (Kesbangpol) Timor Tengah Selatan, Kecamatan Nunkolo, dan Kepala Desa Putun yang telah memberikan surat izin penelitian.

\section{SPONSOR}

Studi ini mendapat dukungan finansial dari Kemenristek Dikti Republik Indonesia melalui Hibah Pascasarjana.

\section{REFERENSI}

Anisa, L., \& Nurfitria, S. (2015). Dukungan sosial dan dampak yang dirasakan oleh ibu menyusui dari suami. Emphaty Jurnal Fakultas Psikologi Universitas Ahmad Dahlan, 3(1), 16-22. 
Athena, A., \& Rachmalina, S. (2014). Kesehatan ibu dan bayi yang melakukan tradisi sei dan gambaran kesehatan lingkungan rumah bulat (Ume Kbubu) di Kabupaten Timor Tengah Selatan-NTT. Jurnal Kesehatan Reproduksi, 5(1), 59-66.

Badan Pusat Statistik. (2017). Kecamatan Nunkolo dalam angka. Ditemu kembali dari https://timortengahselatankab.bps.go.id/publication/2017/09/20/0440d23120e1 ee571e90587 7/kecamatan-nunkolo-dalam-angka-2017

Christiani, N. R., Budiyono, \& Onny, S. (2018). Hubungan kondisi kesehatan rumah bulat suku Dawan \& tradisi sei dengan kejadian ISPA pada bayi di puskesmas Kuanfatu, Kecamatan Kuanfatu. Jurnal Kesehatan Masyarakat, 6(4), 496-504.

Cohen, S., \& Syme, L. (1985). Issues in the study and application of social support. Dalam S. Cohen \& S. L. Syme (Eds.), Social support and health (hlm. 3-22). San Fransisco, CA: Academic Press.

Cremonese, L., Lais, A. W., Lisie, A. P., Cristiane, C. P., Graciela, D. S., \& Lucia, B. R. (2017). Social support from the perspective of postpartum adolescent. Esc Anna Nery, 21(4), 1-8. doi: 10.1590/2177-9465-ean-2017-0088

Dennis, C. L., \& Hodnett, E. (2007). Psychosocial and psychological interventions for treating postpartum depression. Intervension Review, 4, 1-16. doi: 10.1002/14651858.CD006116.pub2

Dinas Kesehatan Nusa Tenggara Timur. (2014). Profil kesehatan tahun 2014. Ditemu kembali dari: http://www.depkes.go.id/resources/download/profil/PROFIL_KES_PROVINSI_2014/19_N TT_2014.pdf.

Dewi, K. (2018). Penyembuhan baby blues syndrome dan postpartum depression melalui Chandra Namaskara dan Brahmari Pranayama. Yoga dan Kesehatan, 1(1),1-14.

Dhanang, D. (2016). Telusuri: Menempa generasi Timor dengan nenoboha. Ditemu kembali dari http://telusuri.org/explore/123/menempa-generasi-timor-denganneno-boha//

Fairus, M., \& Widiyanti, S. (2014). Hubungan dukungan suami dengan kejadian depresi postpartum pada ibu nifas. Jurnal Kesehatan Metro Sai Wawai, 7(1), 11-18.

Goldberger, L., \& Breznitz S. (1982). Handbook of stress theoretical and clinical aspect book 1. New York, NY: Free Press.

Haga, S. M., Ulleberg, P., Slinning, K., Kraft, P., Steen, T. B., \& Staff, A. (2012). A longitudinal study of postpartum depressive symptoms: Multilevel growth curve analyses of emotion 
regulation strategies, breastfeeding, self-efficacy, and social support. Arch Womens Ment Health, 15(3), 175-184. doi: 10.1007/s00737-012-0274-2

Herlina, Widyawati, \& Maryono, S. (2009). Hubungan tingkat dukungan sosial dengan tingkat depresi pada ibu postpartum. Jurnal Ilmu Kesehatan, 4(1), 24-31.

Karwur, F., Yamri, F. S., \& Kristiani, D. T. (2016). Ume Kbubu di sepanjang Dusun II Desa Binaus. Dalam Y. Y. Ranimpi (Ed.), Binaus, wajah pedesaan Timor di abad XX (hlm. 1732). Salatiga: Universitas Kristen Satya Wacana.

Kef, S. (2002). Psychological adjustment and the meaning of social support for visually impaired adolescents. Journal of Visual Impairment \& Blindness, 9(6), 22-37.

Kitzinger, S. (1988). Breastfeeding your baby (revised version). London: Knopf.

Lake, R. C. H. (2014). Konsep ruang dalam dan ruang luar arsitektur tradisional suku Atoni di kampung Tamkesi di Pulau Timor. E-Journal Graduate Unpar, 1(2), 62-74.

Negron, R., Martin, A., Almog, M., Balbierz, A., \& Howell, A. (2013). Social support during the postpartum period: Mothers' views on need, expectations, and mobilization of support. Maternal and Chil Health Journal, 17, 616-623. doi: 10.1007/s10995-012-1037-4

Nevid, J. S., \& Rathus, S. A. (2005). Psikologi abnormal (5th ed.). Jakarta: Erlangga.

Oktaputrining, D., Susandi, C., \& Suroso, S. (2017). Post partum blues: Pentingnya dukungan sosial dan kepuasan pernikahan pada ibu primipara. Jurnal Psikodimensia, 16(2), 151-157. doi: $10.24167 /$ psiko.v16i2.1217

Prapunoto, S., Mage, M., \& Wattimury, C. (2019). Perempuan dalam kelindan ritual budaya: Perjuangan di balik makna hidup. Yogyakarta: Andi.

Sugiyono. (2011). Metode penelitian kuantitatif, kualitatif dan R\&D. Bandung: Alfabeta.

Taylor, S. E., Letitia A. P., \& David O. S. (2009). Psikologi sosial (12th ed.). Jakarta: Kencana Prenada Media.

Webster, J., Nicholas, C., Velacott, C., Cridland, N., \& Fawcett, L. (2011). Quality of life and depression following childbirth: Impact of social support. Midwifery, 27(5), 745-749. doi: 10.1016/j.midw.2010.05.014

Werdayanti, R. (2013). Bapak ASI dan ibu bekerja menyusui. Yogyakarta: Familia.

Zittel-Palamara, K. Cercone, S., \& Rockmaker, J. R. (2009). Spiritual support for women with postpartum depression. Journal of Psychology \& Christianity, 28(3), 213-223. 